\title{
第七回基礎䍞學談話 會
}

1. 日時 1 月 17 日 (火) 於小溝堂

1. 細胞間物質, 特飞銀纎維の本体飞関する文献的考察 病理 草 薙 正之

2. 日本人の管骼の特徵に就て解剖横尾教授

\section{細胞間物質特に銀繊維の本態に關する文献的考察}

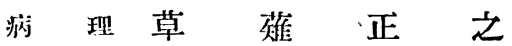

銀䊼維生成機權の細胞起原說と細胞外生成說とに就 て, 今京での文献の內椇味ある名のを紹介し其の考察 をしてみたいと思ふ。

細胞起原說を主張するものには, 1940 Stearns の生 體組織の直接觀察報告がある。 Stearns はウサギの耳 に圆形の孔をあけその組織做換部に於ける組織再生現 象を䘽察し，其際縺維芽細胞內の原形質に暗い顆粒が 突起の方へ移動し其の突起の冈部に於て顆粒より細い 繊維が生ずると云つてるる。

細胞外生成說を主張するものには, 1930 Nageotte の賽蛤的生成がある。Nageotte は大黑鼠の琏を薄い醋 酸液の中に投じて一種の蛋白質を得，此に 0.4 2.0\%

て銀絨維を生成してるる。

以上二諮の報告よりすれば，更に次の問題が殘され てるると思ふ。それは (1) 細胞原形質そのるのが細胞 の突起として細長くのびてそのま入䋞維となるのか, （2）細胞內ですでに緎維の形でできたるのか潬獨に細 胞の外一放出されるか，(3) 細胞間質が細胞から分泌 されそのものの中に織維が析出されるのか，(4) 細胞 間質の中に織維の原料は既存しこれに細胞から分泌さ れる醭素などが作用することに依つて䋐維の形をとる

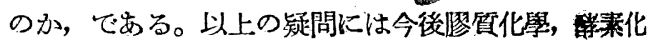
學などの生體領域への進出の倾向か溡に重大な役㓶を 濒ずるのではなかららか。
\end{abstract} 食祭水を加一乳白色の溷濁を生じをるのを固定染色し

\section{日本人骨格の特徵に就て}

日本人頭骨を, 蒙古人仪馬來人の頭骨に較べて見る と, 先づその容積は, 殆ど蒙古人と同樣の大いさで, 馬來人よりは大きい。その腦部の長, 幅, 高 3 徑に いて見ると，蒙古人との間に長徑では差がないが，幅 徑は日本人で劣り，高俓は反對にはつきり優つてる る故に蒙古人では著るしい短頭且低頭であるのに, 日 本人で中頭且高頭の特徵が女り, この點では, 一般 に日本人頭骨の徑にや」劣る馬來人頭骨と殆ど一致す る。

頭蓋底では, 日本人は蒙古人と較ぺても, 馬來人と 較べても, 長俓が少し大きく,大後頭孔の長・幅䣆は小 さい。大後頭孔長斬の前方への倾斜は弱い。顽蓋冠の
解剖橫尾教授

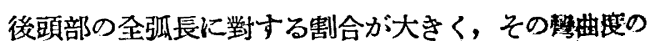
强いことが，蒙古人頭骨の特徴で，馬來人頭骨"せは， その比弧長小さく, 繰曲が弱い。日本人頭骨性, そ の比弧長は蒙古人の如く大きいが，曲は蒙古人程强 くはなく, 馬來人よりは强い。又日本人頭骨て虫，眉 間の隆起や後頭骨筋附着面の凹凸か，蒙古人程㜊くは ないが，馬來人よりは可成り强い。

日本人頭骨の顏面は, 幅俓は馬來人と同程度を り，高俓は，蒙古人と同程度に大さい。故に馬來や蒙

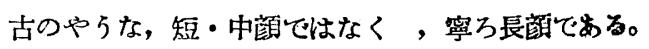

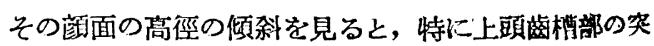
屿著るしく，この點馬來人頭骨と似てみる。 